\title{
Evaluation of an Antimalarial Herbal Recipe and its Individual Plant Extracts for DNA Fragmentation and Clastogenicity Potential in Swiss Albino Mice
}

\author{
${ }^{* 1}$ A. Akinboro, ${ }^{2}$ M. A. Rufai, ${ }^{1}$ R. A. Adeagbo, ${ }^{1}$ A. O. Akanbi, ${ }^{1}$ A. S. Ogunkola, ${ }^{1}$ D. O. Okunola, ${ }^{1}$ T. D. \\ Adeyeye and ${ }^{1} Y . R$. Akanbi \\ 1Department of Pure and Applied Biology, Ladoke Akintola University of Technology, Ogbomoso, Oyo State, Nigeria. \\ 2Zoology Department, Osun State University, Osogbo, Osun State, Nigeria. \\ [ ${ }^{*}$ Corresponding Author: E-mail: aakinboro@lautech.edu.ng; $\left.\mathbf{E}:+2348134727845\right]$
}

\section{ABSTRACT}

In this study, water extracts of leaves of Azadirachta indica and stem bark of Alstonia boonei, and their recipe were evaluated at $25.0 \%, 50.0 \%$ and $100.0 \%$ following DNA fragmentation and micronucleus assays in Swiss albino mice. Distilled water and $0.05 \%$ sodium azide served as negative and positive controls, respectively. The levels of superoxide dismutase, catalase and malondialdehyde in the treated mice were determined. The FTIR technique was adopted to identify the functional groups of phytochemicals present, and the proximate constituents were also determined. The individual extracts of $A$. indica and $A$. boonei were not mutagenic while the recipe was not significantly mutagenic compared to the controls. Water extract of $A$. indica had the least clastogenic activity, while $A$. boonei extract was most cytotoxic towards erythrocytes proliferation. Superoxide dismutase and catalase activities of the extracts and recipe were dose-dependent; however, the recipe at $100.0 \%$ recorded best activity, with highest amount of total proteins. A. indica recorded highest suppression of generation of malondialdehyde molecules. The phytochemicals in the extracts and recipe contained hydroxyl and carbonyl functional groups, and their proximate constituents were almost the same except for the crude protein and fiber contents of the recipe. Conclusively, extract of $A$. indica at the tested doses in this study was found to be less toxic to the mitotic cell division in the bone marrow, DNA and chromosomes in Swiss albino mice than the extract of $A$. boonei and recipe.

Keywords: Azadirachta indica, Alstonia boonei, DNA fragmentation, Micronucleus, Recipe,

\section{INTRODUCTION}

Malaria is a disease of global importance because of high mortality and morbidity it causes among children under five years and pregnant women in the subtropical and tropical regions of the world (Achi et al., 2018; Afolabi and Abejide, 2020). More than 200 million cases of malaria are reported annually and over 420,000 deaths are recorded yearly (Michael and Lawrence, 2019; Bekono et al., 2020). Out of approximately $80 \%$ of mortality from malaria recorded in 13 countries in Africa, Nigeria, Ethopia, Congo, Tanzania and Kenya account for more than 40\% (Afolabi and Abejide, 2020). Malarial parasites develop resistance against the available antimalarial orthodox drugs, and this has necessitated the adoption of alternative herbal remedies to treat malarial infection (Bhatnagar and Das, 2007). The use of herbal medicines to treat malaria is a common practice in most parts of African and Asian continents where infestation by malarial parasites is endemic. In the recent past, several researches have been conducted on the antimalarial activity of many single plant extract or combined extracts preparations (Omoya and Oyebola, 2019; Afolabi and Abejide, 2020).

The leaves of Azadirachta indica (A. juss) and stem - bark Alstonia boonei (De wild) are used as herbal antimalarial preparations because of their reported efficacy (lyamah and Idu, 2015; Afolabi and Abejide, 2020). Various parts (leaves, bark, root, fruits, seeds, flowers, gum, oil) of $A$. indica and $A$. boonei contain therapeutic phytochemicals that are effective in treating diseases such as malaria, diabetics, rheumatism, helminthiasis, dysmenorrhea, cancer, hypertension, heart diseases, pains, fungi, viral and bacterial 
infections (Adotey et al., 2012; Islas et al., 2020). The phytochemical, tetrahydro -4-((E)-7-hydroxy6,14-dimethyl-15-m-tolylpentadec-13-enyl) pyran2-one (TMDTP) purified from the stem - bark of $A$. boonei was reported to be a potent inhibitor of lactate dehydrogenase and plasmepsin II enzymes present in Plasmodium falciparum hence validating the folkloric use of this plant in preparing antimalarial herbal decoction and recipe (Olanlokun et al., 2019). Compounds such as nimbin, azadirachtin, nimbidiol, quercetin, nimbidin have been purified from $A$. indica plant (Rajkumar et al., 2011; Islas et al., 2020). Although many antimalarial herbal medicines have been reported to be effective when prepared from one plant's extract, however, their potency is usually boosted when two or more plants' extracts are combined (Agbedahunsi et al., 2016; Mehrdzadi et al., 2020). The preference to use the mixture of extracts over a single extract as an antimalarial herbal medicine is based on the belief that combination of plants extracts cures some other complications that come with malaria (Odugbemi et al., 2007).

In Nigeria, a significant number of people result to the use of locally prepared antimalarial herbal medicines without considering possible toxicity that may result. It is of great importance to screen herbs for possible toxicological properties since many medicinal plants' constituents at certain doses or concentrations could act as free radical scavengers or free radical producers (Madić et al., 2019). The principle of having more than one plant in formulations of herbal medicines makes their toxicological evaluation necessary for both individual extracts and the extracts' mixture (recipe) in order to establish whether the chemical constituents of each plant undergo a synergistic or antagonistic reaction to bring about toxicity or efficacy. Studies on toxicological evaluation of individual medicinal plants extracts are severally reported (Akinboro and Bakare, 2007; Akinboro et al., 2017; Akinboro et al., 2020b; Pereira et al., 2020). Isaac et al. (2020) reported cytotoxic and antioxidant effects of five commonly used antimalarial herbal mixture in
Ghana. Nevertheless, information on toxicity of extracts' mixture (recipe) is rare and scanty in Nigeria.

This study investigated the effects of a commonly used antimalarial herbal recipe and its individual extracts on some in vivo antioxidant enzymes, DNA and chromosomes of Swiss albino mice.

\section{MATERIALS AND METHODS Collection of Plants}

Fresh leaves of Azadirachta indica (A. juss) were collected from the botanical garden, and stembarks of Alstonia boonei (Di wild) were gotten from the tree around the New Biology Laboratory, Ladoke Akintola University of Technology, Ogbomoso, Oyo State, Nigeria. The plants were duly identified and given identification numbers LHO 582 (Azadirachta indica), LHO 583 (Alstonia boonei) by a renowned taxonomist, Professor A.T.J. Ogunkunle, Pure and Applied Biology Department, LAUTECH, Ogbomoso, Nigeria.

\section{Preparation of Extract and Recipe}

After washing each of the plant parts with clean water and then air-dried, they were separately ground in an electric grinder (Wing, Malaysia). One hundred grams of powdered part of $A$. indica and $A$. boonei were each mixed with $500 \mathrm{ml}$ of distilled water then placed on a hot plate (Binatone) set at $64^{\circ} \mathrm{C}$ for 2 hours 15 minutes for extraction of phytochemicals. The plants extracts recipe was prepared by taking $50 \mathrm{~g}$ each of the powdered leaves and stem bark, respectively and then mixed in $500 \mathrm{ml}$ distilled water. The extraction was carried out as earlier described. Each of the prepared extracts were allowed to cool before sieving using a Whatman filter paper (No 1). Thereafter, the filtrates were stored in a refrigerator at $4^{\circ} \mathrm{C}$ for further use (Akinboro et al., 2017).

\section{Grouping of Experimental Animals}

All experimental procedures pertaining to the use of animals in this study were in line with the internationally accepted guidelines for the use and treatment of animals in behavioral research 
and teaching (Sherwin, 2006). Fifty-five female albino mice used for this study were kept in cages in the animal house facility of the Department of Pure and Applied Biology, LAUTECH and allowed to acclimatize for 1 week. They were fed with commercially formulated feed (Glorivet animal feeds company) and clean water ad libitum throughout the period of the experiment. The animals were weighed and divide into 5 mice per each treatment group at $25.0 \%, 50.0 \%$ and $100.0 \%$ doses $(\mathrm{w} / \mathrm{v})$. The animals in the negative and positive control groups were administered distilled water and sodium azide (0.05\%), respectively. A. indica, $A$. boonei extracts and the recipe were separately administered $(0.1 \mathrm{ml}$ per $10 \mathrm{~g} \mathrm{~b} / \mathrm{w}$ ) for 2 days (24 hours' interval) (Akinboro et al., 2020a).

\section{Micronucleus Assay}

The animals were sacrificed using cervical dislocation and then dissected open in order to remove the femurs and placed in petri dishes containing normal saline. The blood tissue in the femur was flushed into test tubes using $0.5 \mathrm{ml}$ of Hank's balanced salt solution (HBSS). The mixture of blood cells and HBSS was centrifuged at $4000 \mathrm{rpm}$ and the supernatant was decanted. The pellet was reconstituted with freshly prepared $0.2 \mathrm{ml} \mathrm{HBSS}$. A thin blood smear was prepared from the suspension and allowed to air-dry for 3 hours, after which the slides were then fixed with absolute glacial methanol overnight Abhishwk and Alok, 2019). Four slides were prepared from each harvested femur. The slides were then stained with 10\% May Gruenwald and 5\% Giemsa for 10 minutes (Akinboro et al., 2014; Abhishek and Alok, 2020). The stained slides were air dried and blindly scored by observing and counting three hundred micronucleated polychromatic erythrocytes (MNPCE stained purple) and micronucleated normochromatic erythrocytes (MNNCE stained pink or red), polychromatic erythrocytes (PCE, immature erythrocytes) and normochromatic erythrocytes (NCE, matured erythrocytes) (per slide) under immersion oil objective lens (100x) (Akinboro et al., 2014).

\section{DNA fragmentation test}

One gram of liver tissue was homogenized in 10 $\mathrm{ml}$ of Tris-Ethylenediaminetetra acetic buffer $(\mathrm{pH}$ 7.4) using a mortar and pestle under ice (Wu et al., 2005; Saboo et al., 2012) then centrifuged at $4000 \mathrm{rpm}$ for 10 minutes. The supernatant was recovered and used to assay for fragmented DNA using a freshly prepared Diphenylamine (DPA) solution. The absorbance of the reaction mixture was taken at $620 \mathrm{~nm}$. The percent fragmented DNA was determined using the formula below.

\section{Fragmented DNA (\%) \\ $=\frac{\text { Absorbance of supernatant }}{\text { Absorbance of pellet }+ \text { Absorbance of supernatant }} \times 100$ \\ Antioxidant Assays \\ Malondialdehyde (MDA) Determination}

The amount of thiobarbituric acid (TBA) reactive substances (TBARS) produced during lipid peroxidation was determined as described by Ohkawa et al. (1979). Briefly, $0.4 \mathrm{ml}$ of the liver homogenate sample was mixed with $1.6 \mathrm{ml}$ of 0.1 $\mathrm{M}$ Tris-KCl buffer ( $\mathrm{pH}$ 7.4).To this, $0.5 \mathrm{ml}$ of $30 \%$ Trichloroacetic acid (TCA) was added followed by $0.5 \mathrm{ml}$ of $0.75 \%$ TBA. The mixture was then placed in a water bath at $80^{\circ} \mathrm{C}$ for 45 minutes and then cooled on ice and then centrifuged at $3000 \mathrm{x} \mathrm{g}$ for 15 minutes. The mixture was placed in a spectrophotometer set at $532 \mathrm{~nm}$ to measure the absorbance of the resulting clear pink solution against a reference blank (distilled water). The amount of MDA (resulting from lipid peroxidation) was calculated with the molar extinction coefficient of $1.56 \times 10^{5} \mathrm{M}^{-1} \mathrm{~cm}^{-1}$, using the formula below MDA ( $\mu \mathrm{M} / \mathrm{mg}$ protein) $=\frac{\text { Absorbance } \mathrm{x} \text { Volume of mixture }}{\text { E532nm } x \text { Volume of Sample } \mathrm{x} \text { mg Protein }}$

\section{Determination of Superoxide Dismutase Activity}

The determination of SOD activity followed the method of Mistra and Fridovich (1972) as reported by Adekunle (2012). Briefly, $0.2 \mathrm{ml}$ of 1 in 10 dilution of liver homogenate was added to $2.5 \mathrm{ml}$ of $0.05 \mathrm{M}$ sodium carbonate buffer $(\mathrm{pH}$ 


\section{Akinboro et al. Evaluation of an Antimalarial Herbal Recipe and its Individual Plant Extracts...}

10.2), freshly prepared $0.3 \mathrm{mM}$ adrenaline $(0.3$ $\mathrm{ml}$ ) was added to the mixture and then quickly mixed by inversion before equilibrated in the spectrophotometer. The reaction of the mixture was monitored at $480 \mathrm{~nm}$ for every 30 seconds for 150 seconds. The SOD activity was determined as stated below:

SOD activity $=$

Absorbance $x$ Volume of mixture

E480nm x Sample Vol x mg protein

Molar extinction of SOD at $480 \mathrm{~nm}\left(\mathcal{E}_{480 \mathrm{~nm}}\right)=525$ $\mathrm{M}^{-1} \mathrm{~cm}^{-1}$

\section{Catalase Test}

The amount of catalase enzyme induced by the individual extract of $A$. indica and $A$ boonei as well as the recipe was determined as previously described by Tadayuki et al. (2013). Briefly, the sample was diluted with distilled water at a ratio of 1:49. The assay mixture contained $4 \mathrm{ml}$ of 0.2 $\mathrm{M} \mathrm{H}_{2} \mathrm{O}_{2}$ solution and $5 \mathrm{ml}$ of $0.01 \mathrm{M}$ Phosphate buffer (pH 7.0) in a flat bottom flask of $10 \mathrm{ml}$ capacity. One milliliter of enzyme preparation was added to the reaction mixture at room temperature. One milliliter of the reaction mixture was added to $2 \mathrm{ml}$ of dichromate acetic acid reagent at every 1 minute. The mononuclear velocity constant $\mathrm{k}$ for the decomposition of $\mathrm{H}_{2} \mathrm{O}_{2}$ by catalase was calculated by using the equation for a first - order reaction, according to the equation below:

$$
\begin{aligned}
& \mathrm{H}_{2} \mathrm{O}_{2} \text { remained } \\
& =\frac{\text { Change in absorbance } / \mathrm{min}}{0.171}
\end{aligned}
$$

$\mathrm{H}_{2} \mathrm{O}_{2}$ remained

$\mathrm{H}_{2} \mathrm{O}_{2}$ consumed $=800$ -

$\mathrm{K}_{0}=\mathrm{H}_{2} \mathrm{O}_{2}$ Consumed

Kat $\mathrm{f}=\mathrm{K}_{\mathrm{o}} / \mathrm{mg}$ protein $(\mathrm{ml})$

$\mathrm{K}_{0}=$ the velocity constant of catalase at 0 minute, Kat $\mathrm{f}=$ katalasefeiahigkeit

\section{Determination of Total Protein}

The liver homogenate sample and calibrator each $(25 \mu l)$ was treated with $1 \mathrm{ml}$ of Biuret solution.
The blank sample contained $1 \mathrm{ml}$ Biuret solution (standard). The mixtures were incubated at $37{ }^{\circ} \mathrm{C}$ for 5 minutes. At $540 \mathrm{~nm}$, the absorbance of the liver homogenate sample and calibrator was read against the blank using a spectrophotometer (Caguioa et al., 2019).

Total protein concentration was calculated using the formula:

Totalprotein $\left(\frac{g}{d l}\right.$.)

$=\frac{\text { Abs. of Sample }}{\text { Abs. of Standard }} X 7$ (Calibrator Conc.)

Where Abs = Absorbance

Conversion factor (g/dL) X 144.9

FTIR analysis of the extracts and recipe

Each of the extract of $A$. indica, $A$. boonei and recipe was processed into potassium bromide powdered tablets and then placed on SmartTR ${ }^{\mathrm{TM}}$ Attenuated Total Reflectance (ATR) accessory at room temperature $\left(25^{\circ} \mathrm{C}\right)$. They were scanned using the Nicolet iS10 FTIR spectrophotometer (Thermo Fisher Scientific Inc, Madison, USA) coupled with deuterated triglycine sulfate (DTGS) detector and potassium bromide $(\mathrm{KBr}) /$ Germanium as a beam splitter. The spectra were scanned at wave numbers of $4000-650 \mathrm{~cm}-1$ while connected to the software OMNICver.9.7. Each data point was recorded in three replicates using absorbance mode to facilitate quantitative analysis (Siregar et al., 2018).

\section{Proximate Composition of the Extracts and Recipe}

The proximate tests on the individual extract of $A$. indica, $A$. boonei as well as on the recipe was carried out to determine their crude protein, crude fiber, crude lipid (ether extract), ash and moisture contents in line with the procedure of the Association of Official Analytical Chemist (AOAC, 1990; 2000).

\section{Statistical Analysis}

All data obtained in triplicates were presented as mean \pm standard error or standard deviation and percentage. The mean values of the treatment 
groups were compared with the negative control's mean value, and they were then separated using the Duncan multiple range comparison with ANOVA using SPSS statistical package (version 17.0). The outcomes were considered to be significantly different when $p<0.05$.

\section{Results}

\section{DNA Fragmentation}

The induced DNA fragmentations caused by the water extracts of $A$. indica and $A$. boonei at the tested doses were significantly lower than those of the negative and positive controls $(p<0.05)$, unlike those induced at the tested doses of the recipe (Table 1). The least percent DNA fragmentation was recorded at $25.0 \%$ of $A$. boonei and the highest was induced at $100.0 \%$ recipe. DNA fragmentations caused by the extract of $A$. indica and recipe were inversely proportional to the doses.

Table 1: DNA fragmentation activities of individual and combined water extracts of $A$. indica and $A$. boonei

\begin{tabular}{llll}
\hline Concentration (\%) & $\begin{array}{l}\text { Azadirachta indica } \\
(\%)\end{array}$ & Alstonia boonei (\%) & $\begin{array}{l}\text { A. indica + A. boonei } \\
(\text { Recipe) (\%) }\end{array}$ \\
\hline Distilled water & $35.26 \pm 13.72^{\mathrm{c}}$ & $35.26 \pm 13.72^{\mathrm{d}}$ & $35.26 \pm 13.72^{\mathrm{a}}$ \\
Sodium azide (0.05) & $53.60 \pm 12.18^{\mathrm{d}}$ & $53.60 \pm 12.18^{\mathrm{e}}$ & $53.60 \pm 12.18^{\mathrm{a}}$ \\
$\mathbf{2 5 . 0}$ & $16.43 \pm 5.57^{\mathrm{a}}$ & $7.99 \pm 0.61^{\mathrm{a}}$ & $52.64 \pm 10.51^{\mathrm{a}}$ \\
$\mathbf{5 0 . 0}$ & $11.43 \pm 2.34^{\mathrm{ab}}$ & $13.40 \pm 3.87^{\mathrm{b}}$ & $49.61 \pm 15.08^{\mathrm{a}}$ \\
$\mathbf{1 0 0 . 0}$ & $8.40 \pm 1.69^{\mathrm{a}}$ & $23.99 \pm 0.79 \mathrm{c}$ & $40.83 \pm 16.52^{\mathrm{a}}$ \\
\hline
\end{tabular}

Percentage DNA fragmentation \pm SD value with different superscript alphabets in the same column are significantly different at $p<$ 0.05. (number of animals $=33,3$ animals per dose $\times 9$ treatment groups and 2 controls)

\section{Induction of Micronucleus and Ratio of PCE to NCE}

The recipe induced highest number of micronucleated (MN) cells at $50.0 \%$ dose, while the least was obtained at $25.0 \%$ extract of $A$. indica. However, the individual extracts induced MN cells in a dose-dependent, unlike the recipe. There was no micronucleated cell recorded with the distilled water (negative control). The induced MN cells at $50 \%$ and $100 \%$ doses of the recipe, and at $100 \%$ of the individual extract of $A$. indica and $A$. boonei were significantly different from that recorded with distilled water ( $p \leq 0.05$ ) (Figure 1). The ratio of PCE to NCE induced at the tested doses of water extract of $A$. indica and recipe was not significantly different from that of the negative control ( $p \geq 0.05$ ), except those induced by water extract of $A$. boonei (Table 2). Water extract of $A$. boonei at $25.0 \%$ induced highest ratio of PCE to NCE, while at its $100.0 \%$, the least ratio of PCE to NCE was obtained.

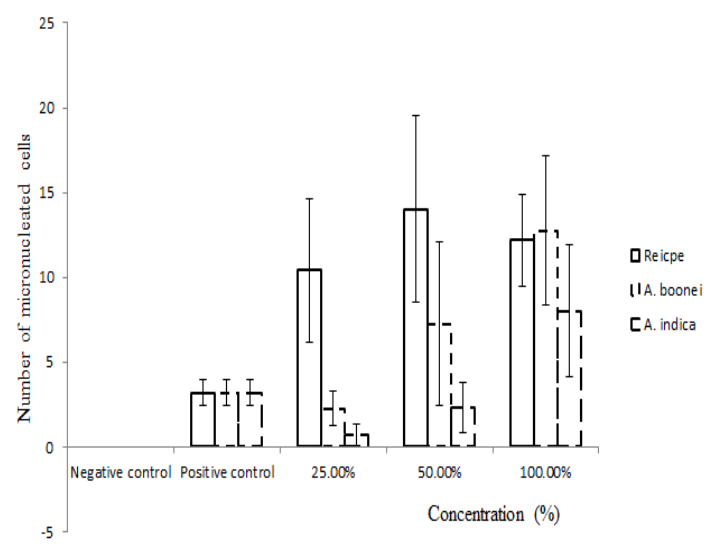

Figure 1: Activity of water extract of $A$. indica, $A$. boonei singly and recipe induction of micronuclei in the bone marrow of Swiss albino mice (number of animals $=33,3$ animals per dose $\times 9$ treatment groups and 2 controls) 
Akinboro et al. Evaluation of an Antimalarial Herbal Recipe and its Individual Plant Extracts...

Table 2: Toxicity of water extract of $A$. indica, $A$. boonei and recipe to erythrocytes proliferation in Swiss albino mice

\begin{tabular}{llll}
\hline CONCENTRATION (\%) & $\begin{array}{l}\text { Azadirachta } \\
\text { indica } \\
\text { PCE:NCE } \pm \text { SE }\end{array}$ & $\begin{array}{l}\text { Alstonia boonei } \\
\text { PCE:NCE } \pm \text { SE }\end{array}$ & $\begin{array}{l}\text { A. indica }+ \text { A. boonei } \\
\text { (Recipe) } \\
\text { PCE:NCE } \pm \text { SE }\end{array}$ \\
\hline Distilled water & $2.48 \pm 1.00^{\mathrm{a}}$ & $2.48 \pm 1.00^{\mathrm{c}}$ & $2.48 \pm 1.00^{\mathrm{a}}$ \\
Sodium azide (0.05) & $1.81 \pm 0.7^{\mathrm{a}}$ & $1.81 \pm 0.7^{\mathrm{b}}$ & $1.81 \pm 0.7^{\mathrm{a}}$ \\
$\mathbf{2 5 . 0}$ & $3.34 \pm 1.39^{\mathrm{a}}$ & $29.81 \pm 13.99 \mathrm{a}$ & $1.27 \pm 0.46^{\mathrm{a}}$ \\
$\mathbf{5 0 . 0}$ & $2.56 \pm 0.50^{\mathrm{a}}$ & $6.87 \pm 5.63^{\mathrm{d}}$ & $2.03 \pm 0.25^{\mathrm{a}}$ \\
$\mathbf{1 0 0 . 0}$ & $2.23 \pm 0.30^{\mathrm{a}}$ & $0.40 \pm 0.09^{\mathrm{a}}$ & $2.48 \pm 0.69^{\mathrm{a}}$ \\
\hline
\end{tabular}

Values with different superscript alphabets in the same column are significantly different at $p<0.05$, (number of animals $=33,3$ animals per dose $\times 9$ treatment groups and 2 controls)

\section{Antioxidant activity}

The Superoxide dismutase and catalase levels in the mice administered with the extract of $A$. indical, A.boonei, and recipe increased in a dose dependent manner. The superoxide dismutase activity (Figure $2 \mathrm{a}$ ) was best at $100.0 \%$ recipe which recorded almost double antioxidant activity of those obtained at the lower doses. The catalase activity of $A$. boonei was the best at $25.0 \%$ and $50.0 \%$ doses, however, the catalase

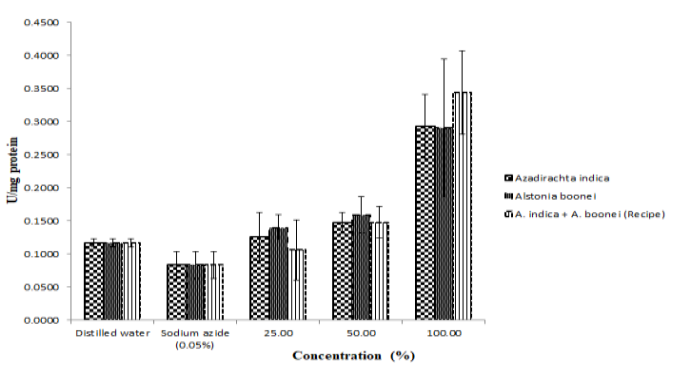

Figure 2a: Superoxide dismutase activity of water extracts of $A$. indica, $A$. boonei and their recipe in Swiss albino mice (number of animals $=33,3$ animals per dose $\times 9$ treatment groups and 2 controls) activity (Figure $2 b$ ) of the recipe at $100.0 \%$ dose was slightly higher than that of $A$. boonei. The generation of malondialdehyde products of lipid peroxidation (Figure 2c) was the lowest at $100 \%$ of $A$. indica, and this was inversely proportional to the doses of this plant extract. Individual extract of $A$. indica and $A$. boonei generated highest amount of malondyaldehyde at 50\%, while sodium azide showed the poorest anti-lipid peroxidation activity

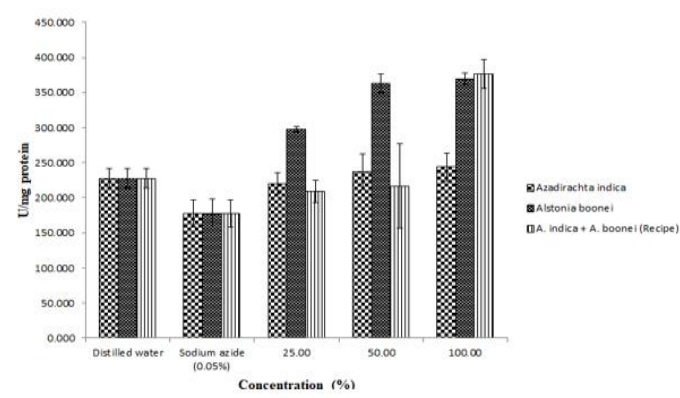

Figure 2b: Catalse activity of water extracts of $A$. indica, $A$. boonei and their recipe in Swiss albino mice

(number of animals $=33,3$ animals per dose $\times 9$ treatment groups and 2 controls). 


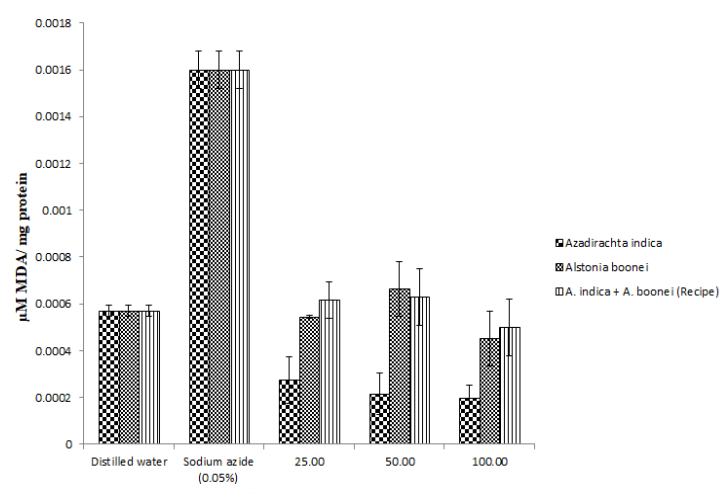

Figure 2c: Malondialdhyde activity of water extracts of $A$. indica, $A$. boonei and their recipe in Swiss albino mice (number of animals $=33,3$ animals per dose $\times 9$ treatment groups and 2 controls)

The amounts of total protein detected in the liver of mice administered with the extracts and recipe are presented in Table 3. The highest and least amounts of protein were induced at $25.0 \%$ recipe, and $25.0 \%$ and $50.0 \%$ A. boonei, respectively. The amounts of total protein induced at $25.0 \%$ and $100.0 \%$ recipe were significantly different from those caused at other doses used in this study.

Table 3: Total protein in the liver of Swiss albino mice administered with extract of $A$. indica, $A$. boonei and recipe

\begin{tabular}{llll}
\hline & \multicolumn{3}{c}{ TOTAL PROTEIN $(\mu \mathrm{g} / \mathrm{mL})$} \\
Dose (\%) & A. indica & A. boonei & Recipe \\
\hline Distilled water & $0.047 \pm 0.007^{\mathrm{a}}$ & $0.047 \pm 0.007^{\mathrm{a}}$ & $0.047 \pm 0.007^{\mathrm{a}}$ \\
Sodium azide & $0.037 \pm 0.014^{\mathrm{a}}$ & $0.037 \pm 0.014^{\mathrm{a}}$ & $0.037 \pm 0.014^{\mathrm{a}}$ \\
$\mathbf{2 5 . 0 \%}$ & $0.039 \pm 0.001^{\mathrm{a}}$ & $0.027 \pm 0.006^{\mathrm{a}}$ & $0.253 \pm 0.204^{\mathrm{b}}$ \\
$\mathbf{5 0 . 0 \%}$ & $0.044 \pm 0.007^{\mathrm{a}}$ & $0.027 \pm 0.000^{\mathrm{a}}$ & $0.035 \pm 0.009 \mathrm{a}$ \\
$\mathbf{1 0 0 . 0 \%}$ & $0.044 \pm 0.002^{\mathrm{a}}$ & $0.039 \pm 0.006^{\mathrm{a}}$ & $0.079 \pm 0.014^{\mathrm{ab}}$ \\
\hline
\end{tabular}

(number of animals $=33,3$ animals per dose $\times 9$ treatment groups and 2 controls)

\section{FTIR Analysis}

The clear and broad peak at wavenumber at $3270.7 \mathrm{~cm}^{-1}$ in the FTIR spectra of the recipe, corresponded to stretching vibration of hydroxyl group, the peaks at wavenumbers $1538.2 \mathrm{~cm}^{-1}$ and $1015.7 \mathrm{~cm}^{-1}$, corresponded to stretching vibrations of carbonyl and carbon - carbon functional groups, respectively. The extract of $A$. boonei showed a broad and clear peak at wavenumber $3283.1 \mathrm{~cm}^{-1}$ corresponding to stretching vibration of hydroxyl functional group, while the peak at wavenumber $1638.2 \mathrm{~cm}^{-1}$ represented carbonyl functional group. The FTIR spectra of chemical molecules in the phytochemicals of $A$. indica showed two peaks (one broad and clear) at wavenumbers
$3289.4 \mathrm{~cm}^{-1}$, and $1638.2 \mathrm{~cm}^{-1}$ corresponding to stretching vibrations of hydroxyl and carbonyl functional groups, respectively (Figures 3a-c).

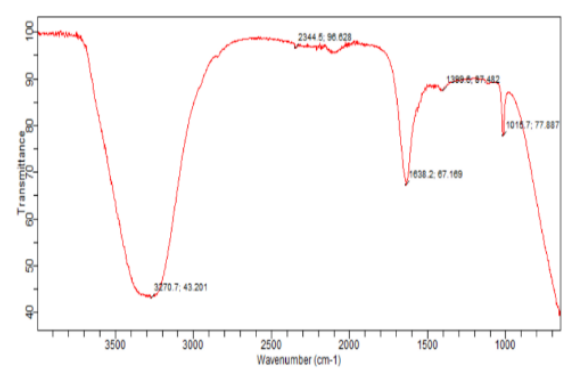

Figure 3a: FTIR spectra of functional groups detected in the recipe 


\section{Akinboro et al. Evaluation of an Antimalarial Herbal Recipe and its Individual Plant Extracts...}

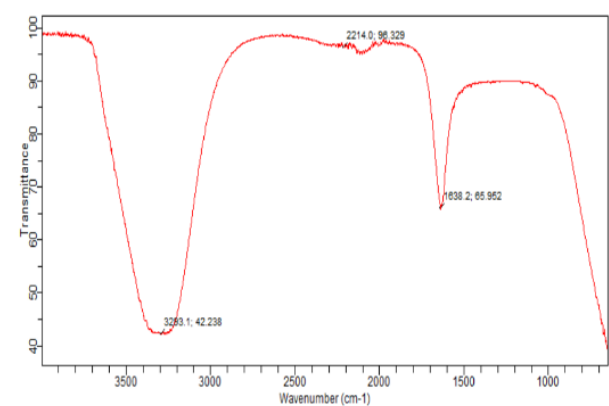

Figure 3b: FTIR spectra of functional groups detected in the water extract of $A$. boonei

\section{Proximate analysis}

Table 4 shows that the protein content ranged between $2.64 \%$ to $5.25 \%$, while it was in the range of $0.40 \%$ to $0.42 \%$ for the crude fibre.

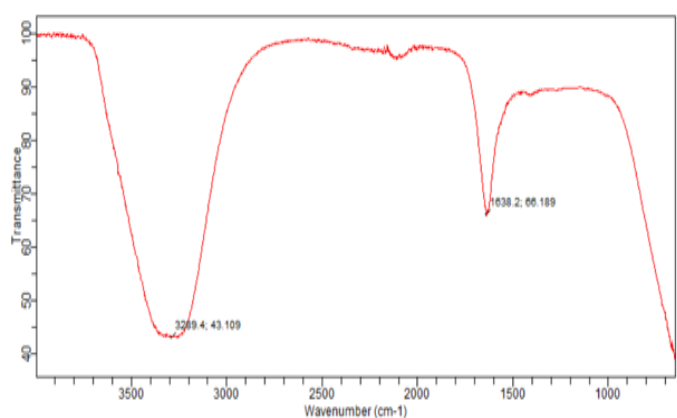

Figure 3c: FTIR spectra of functional groups detected in the water extract of $A$. indica.

Moisture content, ash and crude lipid or ether extract were $98.0 \%, 1.0 \%$, and $1.8 \%$, respectively for the recipe, $A$. boonei and $A$. indica.

Table 4: Proximate analysis of individual extracts of $A$. indica, $A$. boonei and a recipe made from the two plants

\begin{tabular}{lrrrrrr}
\hline EXTRACT & $\begin{array}{l}\text { CRUDE } \\
\text { PROTEIN } \\
(\%)\end{array}$ & $\begin{array}{l}\text { CRUDE } \\
\text { FIBRE } \\
(\%)\end{array}$ & $\begin{array}{l}\text { CRUDE } \\
\text { LIPID } \\
(\%)\end{array}$ & $\begin{array}{l}\text { MOISTURE } \\
(\%)\end{array}$ & $\begin{array}{l}\text { ASH } \\
(\%)\end{array}$ \\
\hline A. indica & 3.5 & 0.41 & 1.8 & 98 & 1 \\
& & & & & \\
A. boonei & 2.64 & 0.4 & 1.8 & 98 & 1 \\
Recipe & 5.25 & 0.42 & 1.8 & 98 & 1 \\
\hline
\end{tabular}

\section{DISCUSSION}

It is a common practice in the developing and developed countries to use natural medicines for prevention and treatment of diseases. The healing potency of medicinal plants depends on the kind of phytochemicals in them. However, while some phytochemicals are for healing, some of them could be toxic under certain conditions; hence, the need for toxicological screening of medicinal plant extracts, either individually or in combination / mixture (as recipes). Individual water extract of Azadirachta indica and Alstonia boonei in this study could be said to be nonmutagenic based on induction of lesser percent of DNA fragmentation, in the liver cell of Swiss albino mice than that of the negative control. These results are in accordance with the effects of n-hexane extract of Uvaria chamae stem on selected liver tissue of mice (Akolade et al., 2018). However, the percentage DNA fragmentations caused by the recipe which were higher than that of the negative control but not significantly different, and were not induced in a dose-dependent manner suggests weak 


\section{Nigerian Journal of Basic and Applied Science (December, 2021), 29(2):89-101}

mutagenicity. The higher total proteins induced by the recipe than each of the extract of $A$. indica and $A$. boonei might have resulted from the higher quantity of DNA repairs enzymes (proteins) needed to be produced / synthesized in the mice administered with the recipe in order to take care of the genotoxicity of the recipe. These results are not similar to the mutagenic activity of water and aqueous extract of $A$. indica and $A$. boonei previously reported in the cells of Allium cepa, Salmonella tryphimurium, Plasmodium falciparum, and human peripheral mononuclear cells (Akinboro and Bakare, 2007; Akaneme and Amaefule, 2012; Serlome et al., 2020).

Different test organisms used for the previous and present experiments could be responsible for dissimilarity in the results of activity of the plants extracts. DNA damaging activity of a chemical substance has been attributed to prevention of synthesis of DNA precursors or blockage of incorporation of these precursors into S-phase of the cell cycle, consequently leading to complete arrest of mitosis or cell death. The induction of micronucleated cells at the doses of individual extracts and recipe as well as the positive control suggests clastogenic effect. However, the reduction of this effect at $100.0 \%$ of the recipe indicates that this effect was not synergistically promoted by the combined extracts of $A$. indica and $A$. boonei in the recipe. Root extract of $A$. boonei was reported to have low clastogenic effect in A. cepa cells (Egonu et al., 2019). In contrast, seed oil of $A$. indica was said to have non-clastogenic activity following the mouse bone marrow micronucleus assay (Vinod et al., 2011).

Different parts of the plants and methods of extracts preparation used in this study could be responsible for the variation in the results. Water extract of $A$. boonei at $100.0 \%$ was able to suppress erythrocytes proliferation better than extract of $A$. indica and the recipe. This effect that was synergistically promoted at $25.0 \%$ and $50.0 \%$ of the recipe justifies the combination of these plants to formulate an antimalarial herbal recipe of this kind in the Southwest Nigeria. The suppression of erythrocytes proliferation is an indication of antimitotic activity of the individual extracts and recipe. This effect was cytotoxic, and it could be one of the mechanisms by which they display their antimalarial healing properties in Plasmodium falciparum parasitized human host. This further supports their folkloric antimalarial properties of being cytotoxic to plasmodium cells. However, the non-dose dependent toxicity of the recipe to the proliferation of erythrocytes is a sign of weak cytotoxic effect. The antioxidant activity of individual water extract of $A$. indica, $A$. boonei and the recipe in terms of superoxide dismutase and catalase induction that was dose dependent and highest at $100.0 \%$ of the recipe suggests good antioxidant potential. This activity could have been promoted synergistically in the recipe especially at its absolute dose $(100.0 \%)$. This was corroborated with the highest amount of total protein recorded with the mice administered with the recipe. Water extract of $A$. boonei seems to possess better antioxidant activity as it induced higher concentrations of superoxide dismutase and catalase than water extract of $A$. indica and the recipe at $25.0 \%$ and $50.0 \%$. Production of malondialdehyde metabolites of lipid peroxidation of cell membrane caused by the individual extract and recipe showed that water extract of $A$. indica possessed best anti-lipid peroxidation activity as it caused dose-dependent reduction in the amount of malondialdehyde generated in the mice administered with the extract. Polar solventextracts of $A$. indica and $A$. boonei have been known for their antioxidant activity associated with phenolic phytochemicals.

The FTIR spectra of the individual extracts and their combination indicated the presence of similar functional groups, suggesting possibility of them having the same kind of phytochemicals. The broad peaks of hydroxyl functional group at $3270.7 \mathrm{~cm}-{ }^{-1}, \quad 3283.1 \mathrm{~cm}^{-1}$ and $3289.4 \mathrm{~cm}^{-1}$, respectively for the recipe and each of the extracts of $A$. boonei and $A$. indica could have been dissociated from phenolic compounds, carbohydrates or alkaloids present in them. 
Akinboro et al. Evaluation of an Antimalarial Herbal Recipe and its Individual Plant Extracts...

Phytochemicals such as phenolic compounds, tocopherol, carotenoids and ascorbic acid reported in aqueous extracts of $A$. indica and $A$. boonei are associated with the antioxidant activity of these plants (Afolabi et al., 2007; Sujita et al., 2019). The results of the proximate analysis of the individual extracts and recipe showed the presence of the same constituents. The recipe contained highest amount of crude protein possibly because the synergistic reaction between the crude proteins in each of the water extracts of $A$. boonei and $A$. indica. The usage of individual plant extracts and their combination for the treatment of malaria could be justified because of the presence of similar phytochemicals. The combination of these plants to form an herbal recipe is a practice that aims at boosting the potency of herbal medicines because plants have various phytochemicals and minerals that sometimes work, synergistically to better the health condition of a diseased body, or I and, possibly antagonistically to induce toxicity.

\section{CONCLUSION}

The findings in this study have shown that extract of $A$. boonei was most cytotoxic to the bone marrow cells of mice. The individual extract of $A$. indica and $A$. boonei was not mutagenic, but had clastogenic effect at $100.0 \%$. The recipe was not significantly mutagenic, but was clastogenic at $100.0 \%$. The recipe contained highest amount of total protein and showed the best antioxidant activity (SOD and CAT).

A. indica extract had the best activity against the generation of malondialdehyde molecules. The observed biological activities might have been due to the presence of antioxidant phytochemicals containing hydroxyl and carbonyl functional groups. Water extract of $A$. indica was the least toxic in this study.

\section{Conflicts of interest:}

The authors declare no conflict of interest.

\section{REFERENCES}

Abhishek, K.J., \& Alok, K.P. (2019). In Vivo Micronucleus Assay in Mouse Bone Marrow, Alok Dhawan and Mahima Bajpayee (eds.),Genotoxicity Assessment: Methods and Protocols, Methods in Molecular Biology.Springer Science+Business Media, LLC part of Springer Nature 2019 - 2031,

Achi, N.K, Chimaraoke, O., Daniel, A.N., Chima, A.E.E., Igwe, K. K., Ikedichim, C.C., \& Grace, C.W. (2018). Therapeutic effects of Azadirachta indicaA.Juss. leaves in malaria induced male Wistar rats. Journal of Pharmacy \& Pharmacognosy Research, 6(3): 191-204.

Adekunle, A.S. (2012). Oxidative Stress in Biochemical, Seminological and Histological Alterations Due to Acute Administration of Intramuscular Artemether in Mice. Researcher, 4(3): 9 17.

Adotey, J.P.K., Genevieve, E. A.,Yaw, O.B., Frederick, A.A. (2012).A Review of the Ethnobotany and Pharmacological Importance of Alstonia boonei De Wild (Apocynaceae),International Scholarly Research NetworkISRN Pharmacology. Article ID 587160.

Afolabi, O.J., \& Abejide, A. E. (2020). Antiplasmodial activities of Morinda lucida(Benth) and Alstonia boonei(De wild) inmice infected with Plasmodium berghei. Bulletin of the National Research Centre, 44:85.

Afolabi, C. A., Ibukun, E. O., Emmanuel A., Akinrinlola, B. L., Onibon, T. R., Akinboboye A. O., Obuotor, E. M., Farombi, E. O. (2007) Chemical constituents and antioxidant activity of Alstonia boonei, African Journal of Biotechnology, 6(10): 1197-1201.

Agbedahunsi, J.M., Adepiti, A.O., Adedini, A. A, Akinsomisoye, O., \& Adepitan, A. (2016). Antimalarial Properties of Morinda lucidaandAlstonia booneion 


\section{Nigerian Journal of Basic and Applied Science (December, 2021), 29(2):89-101}

Curcuma longa on Quinine in Mice. Journal of Herbs, Spices \& Medicinal Plants, 22:1-10.

Akaneme, F. I., \& Amaefule, C. C. (2012). Evaluation of the cytotoxicity and genotoxicity

of aqueous leaf extracts of Azadirachta indicaA. Jussusing the Allium test. Journal of Medicinal Plants Research, 6(22): 3898-3907.

Akinboro, A., \& Bakare, A. A. (2007). Cytotoxic and genotoxic effects of aqueous extracts of five medicinal plants on Allium cepa Linn. Journal of Ethnopharmacology, 112: 470 - 475.

Akinboro, A., Kamaruzaman, B. M., Mohd-Zaini, \& Yekeen, T. A. (2014). Antimutagenic effects of aqueous fraction of Myristica fragrans (Houtt.) leaves on Salmonella 2 typhimurium and Mus musculus. Acta Biochimica Polonica, 61(4): 779-785.

Akinboro, A., Adedosu, O. T., Famurewa, F. O., Olowe, T.,\& Oyewole, O. O. (2017). Antioxidant, Proximate and Cytogenotoxic Evaluation of Anti-typhoid fever herbal recipe in Allium cepa cells. Global Journal of Bio-Science and Biotechnology, 6(1): 24-29.

Akinboro, A., Kamaruzaman, M. \& Zaini, A.(2020a). Effects of rutin in Myristica fragrans Houtts. against cyclophosphamide-induced genotoxicity in sperm cells, on liver and kidney tissue, in Swiss Albino mice. American Journal of Physiology, Biochemistry and Pharmacology, 10(1): 7-17.

Akinboro, A., \& Soremekun, S. I. (2020b). Cytogenotoxicity evaluation of water extract of Lawsonia inermis (Henna) following the Allium cepa root mitosis assay,Science focus: International Journal of Biological and Physical Sciences, 25: 61-70.

Akolade, O. R., Chinwe, A. S., Olalekan, B. T., Halima, A. T., Fatima, A. A., Emuejevoke, T. T. \& Herbert, C. A. B. (2018) Haematological and Genotoxicity
Evaluations of Phytochemical Compounds from n-Hexane Extract of Uvaria chamae Stem on Selected Organs in Mice. Annals of Science and Technology B, 3: 28-34.

AOAC. (1990) Official methods of analysis of the Association of Official Analytical Chemists. 2 vols. 15th ed. Washington, DC.

AOAC. (2000) Official Methods of Analysis. 17th Edition, The Association of Official Analytical Chemists, Gaithersburg, MD, USA. Methods 925.10, 65.17, 974.24, 992.16.

Bekono,B. D., Ntie-Kang, F., Onguéné, P. A., Lifongo, L. L., Sippl, W., Fester, K., \& Owono, L.C. O. (2020). The potential of anti-malarial compoundsderived from African medicinal plants: A review of pharmacological evaluations from 2013 to 2019, Malarial Journal,19(183):1-35.

Bhatnagar, S., \& Das, P. (2007). Antimalarial Activity in Tropical Plants: A Review,Journal of Herbs, Spices \& Medicinal Plants, 13(1):103-132.

Caguioa, J. J. O., Manundan, J. M., \& Rapanot,J. D. (2019). Measuring Protein Concentration of Bovine Albumin Serum using Spectrophotometric Analysis: A Magnesium Chloride based Biuret Assay, Philippine Normal University College of Graduate Studies and Teacher Education Research, 1 -3.

Egonu, S. N., Abu, N. E.,\& Nma, R. U. (2019). Assessment of the cytotoxicity and genotoxicity of aqueous rootextract of Alstonia booneiDe wild using the Allium test. Nigerian Journal of Biotechnology, 36: 41-46.

Isaac, D., Shaibu, A. A., Regina, A. O., \& Obed, C. (2020). Cytotoxic and Antioxidant Effects of Antimalarial Herbal Mixtures, International Journal of Microbiology, 8645691: 5

Islas, J. F., Ezeiza, A., Zuca, G.B., Juan, L.D.G., María, G.M.T., Bruno, E., \& Jorge, 


\section{Akinboro et al. Evaluation of an Antimalarial Herbal Recipe and its Individual Plant Extracts...}

E.M.C. (2020). An overview of Neem (Azadirachta indica) and its potential impact on health. Journal of Functional Foods, 74(10):41-71.

Iyamah, P. C., \& Idu, M. (2015). Ethnomedicinal survey of plants used in the treatment of malaria in Southern Nigeria, Journal of Ethnopharmacology,173:287 - 302.

Madić, V., Stojanović-Radić, Z., Jušković, M., Jugović, D., Žabar Popović, A., \& Vasiljević, P. (2019). Genotoxic and antigenotoxic potential of herbal mixture and fivemedicinal plants used in ethnopharmacology. South African Journal of Botany, 125:290 -297.

Mehrzadi, S., Mirzaei, R., Heydari, M., Maryam, S., Yaqoob, B., \& Huseini, H. F. (2020). Efficacy and Safety of a Traditional Herbal Combinationin Patients with Type II Diabetes Mellitus: A RandomizedControlled Trial, Journal of Dietary Supplements 1 - 13.

Michael, K. L., \&, Lawrence, S. B. (2019). Antimalarial Efficacy and Toxicological Assessment

of

Extracts of Some Ghanaian Medicinal Plants. Journal of Parasitology Research, 1630405, 9

Mistra, H. P., \& Fridovich, I. (1972). The role of superoxide anion in the autooxidation of epinephrine and a simple assay for superoxide dismutase, Journal of Biological Chemistry, 247(10):3170-3175.

Odugbemi, T. O., Odunayo, R. A., Ibukun,E. A., \& Peter,O. F. (2007). Medicinal plants useful for malaria therapy in Okeigbo, Ondo State, Southwest Nigeria. African Journal of Traditional and Complementary and Alternative Medicines, 4(2):191- 198.

Ohkawa, H., Ohishi, N., \& Yagi, K. (1979). Assay for lipid peroxides in animal tissues thiobarbuturic acid reaction. Analytical Biochemistry, 95(2):351-358.

Olanlokun, J. O., Andrew, F. O., Oluwole, M. D.,Thomas, O., Idowu, E. M. S., \& Olufunso, O. O. (2019). A novel compound purified from Alstoniabooneinhibits Plasmodium falciparumlactate dehydrogenase and plasmepsin II. Journal of Biomolecular Structure and Dynamics, 37: 2193-2200.

Omoya, F., \& Oyebola, T. F. (2019). Antiplasmodial activity of stem bark and leaves ofAlstonia boonei(De Wild). Journal of Microbiology \& Experimentation, 7(5):241-245.

Oppong, B. E., Benjy D. K., Kitcher, C., Gordon, A., Frimpong, M. S., \& Schwinger, G. (2019). Pharmacognostic Characteristics and Mutagenic Studies of Alstonia boonei De Wild. Research Journal of Pharmacognosy, 7(1):7-15.

Pereira, E. D.deM., Silva, J.daC., Patrícia, daS. I. G., Picada, J. N., Júnior, I. B.S, Vasques, G. J., Pereira, M. A. da S., Reginatto, F. H., Falcão, F. A.de B. (2020). In vivo and in vitro toxicological evaluations of aqueous extract from Cecropia pachystachyaleaves, Journal of Toxicology and Environmental Health, Part A, 83(19-20):659-671.

Rajkumar, P., Murari, P., \& Nand, K. S. (2011). Anticancer biology of Azadirachta indicaL (neem). Cancer Biology \& Therapy,12(6):467-476.

Saboo, S. S., Khadabadi, S., \& Tapadiya, G. G. (2012). In vitro Evaluation of Antimitotic, Antiproliferative, DNA fragmentationand Anticancer activity of Chloroform and Ethanol extracts of Revia hypocrateriformis. Asian Pacific Journal of Tropical Disease, S503-S508.

Sherwin, C.M. (2006). Guideline for the treatment of animals in behavioral research and teaching. Animal Behaviour, 71: 245-253.

Serlome, A, Doris, E., Richard, H. A., Alexander, K.N.,Patrick, K. E.,Dominic, A. E.,\& Michael, F. O. (2020). Antiplasmodial and Genotoxic Study of Selected GhanaianMedicinal Plants. EvidenceBased Complementary and Alternative Medicine, 1582724, 10 


\section{Nigerian Journal of Basic and Applied Science (December, 2021), 29(2):89-101}

Siregar, C., Martono, S., Rohman, A. (2018). Application of Fourier transform infrared (FTIR) spectroscopycoupled with multivariate calibration for quantitative analysis ofcurcuminoid in tablet dosage form, Journal of Applied Pharmaceutical Science,8(08):151-156.

Sujita, M., Binita, M., Ram Lal, S. (2019) Antioxidant, antibacterial and GC-MS analysis of methanolic extract of Azadirachta indica Juss, The Pharma Innovation Journal, 8(12): 178-180.

Tadayuki, I., Akiko, T., Shinya, S., Ken-ichi, O., Ippei, H., Yuko, K., Koji, T., \& Yoshimitsu, M. (2013). A Simple Assay for Measuring Catalase Activity: A Visual Approach. Scientific Reports, 3:3081.
Wu, B., Ootani, A., Iwakiri, R., Sakata, Y., Fujise, T., Amemori, S., Yokoyama, F., Tsunada, S., \& Fujimoto, K. (2005). T cell deficiency leads to liver carcinogenesis in Azoxymethane-treated rats. Experimental Biology and Medicine, 231:91-98.

Vinod, V., Tiwari, P. K., Meshram, G. P. (2011).Evaluation of mutagenic and antimutagenic activities of neem (Azadirachtaindica) seed oil in the in vitro Ames Salmonella/microsome assay and in vivomouse bone marrow micronucleus test. Journal of Ethnopharmacology, 134: $931-937$. 